apostle, presumably John, was not only the source, but in a sense the writer, of this book. Yet the book perhaps does not owe its present form to him." He says further : "This material left the hand of the author, moreover, not in the form of the book which we have, but in a number of smaller books." Again he says: "They indicate that the book is mainly from one hand, but they imply also that we may expect to find four strata of material, or rather evidences of four influences at work," of which the fourth is "possibly the blundering work of a copyist or binder." It will thus be seen that Prof. Burton does not think that the Apostle John is the author of the Gospel as we now have it, "but a series of historical sermons" were preached by him which have been added to by a later hand and put together wrong. This is a modification of the views of Wendt and Bacon, and largely destroys the value of the Gospel as orderly and objective history. "In its spirit," he says, "the book is far more the work of a preacher seeking to develop spiritual life, than of an historian seeking to produce an accurate record of past events." We are glad to note that Prof. James Drummond, the Unitarian scholar, of Oxford, in his recent great work on the "Authorship of the Fourth Gospel," accepts the genuineness and integrity of the Gospel of John, though he is not able to take as an historic event the account of the resurrection of Lazarus. The chief stumbling block that many modern scholars find in the Gospel of John is its unequivocal claim and proof of the essential deity of Jesus. But the integrity of the book remains and will remain.

A. T. Robertson

Studies in the Grospel According to Mark. For the use of Classes in Secondary Schools and in the Secondary Division of the Sunday School.

By Ernest DeWitt Burton, Professor in the University of Ohicago The University of Chicago Press. \$1.50.

This volume of the Constructive Bible Studies series is most worthy whether considered in its mechanical execution, and the quality of the material, in its conformity with pedagogical principles, in its extensive illustrations and maps, or in its fitness for inducting the youth into Mark's view of the Christ. 
There is a careful analysis with division into sections with suggestive topics; explanatory notes with each section and questions of three classes, "questions of attention, questions of investigation, questions of reflection and application." A brief, carefully prepared "dictionary" was an essential for such study as the volume contemplates. The dealing with certain words in the dictionary, like some few of the notes on the text, is unsatisfactory in that the doctrine of the deity of Jesus is avoided and the way left open for its denial. No teaching directly antagonistic to this doctrine has been noticed. The personality of the Devil and the reality of demoniacal possession also have some doubt cast on them. Perhaps so much Prof. Burton felt bound in conscience to do in deference of scientific doubt and his own convictions. As a rule, however, Mark is allowed fully to tell his own story and the student is in every way helped to reach the deep teaching and implications of the Gospel.

That there is some demand for such careful studies of Scripture is manifest to any observer. That this demand can be greatly increased should also be obvious. That this is desirable in the highest degree should need no proof.

Teachers and classes that wish really to study this Gospel will find more helpful direction here than in many volumes of the more ponderous sort.

W. O. CARVER.

\section{A History of Education in the United States.}

By Edwin Grant Dexter. The Macmillan Co. 1904.

In this volume of 650 pages the author has given us an admirable sketch of our educational history in all its aspects. The work is divided into three parts. In the first part the author traces the rise of the "People's Schools" in the various sections of the country, the developments in elementary education, the developments in public secondary education, the developments in school organization and administration and closes with an interesting history of text-books.

The second part treats of higher and special education; the rise and history of the most important colleges and universities, the history of theological education, legal 